[Original]

\title{
A Survey on Bacterial Contamination of Lavage Water in Electric Warm-Water Lavage Toilet Seats and of the Gluteal Cleft after Lavage
}

\author{
Hideki Katano $^{1 *}$, Kumi Yokoyama ${ }^{2}$, Yasushi TakeI $^{3}$, Seiki Tazume ${ }^{1}$, Mami TsukisI $^{4}$ and Hideaki Matsuki ${ }^{1}$ \\ ${ }^{1}$ School of Health Sciences, Tokai University, Shimokasuya, Isehara-shi, Kanagawa-ken 259-1193, Japan \\ ${ }^{2}$ School of Health Care and Nursing, Juntendo University, takasu, Urayasu-shi, Chiba-ken 279-0023, Japan \\ ${ }^{3}$ School of Health Sciences and Nursing, Juntendo University, Oomiyacho, Mishima-shi, Shizuoka-ken 411-8787, Japan \\ ${ }^{4}$ Kanagawa University of Human Services, Heiseicho, Yokosuka-shi, Kanagawa-ken 238-8522, Japan
}

\begin{abstract}
Electric warm-water lavage toilet seats are in wide use as an appliance beneficial for the maintenance of hygiene and the prophylaxis and improvement of conditions such as constipation and hemorrhoids. In this study, we surveyed the bacterial content in the lavage water of warm-water lavage toilet seats, and fecal bacterial contamination of the gluteal and genital regions due to droplet infection from post-defecation lavage, to examine the problems inherent to the use of such lavage units. The presence of viable bacteria in lavage water was confirmed in this survey. Viable bacterial counts in lavage water were 3-times higher in household units compared to units in public facilities, suggesting a correlation with the replenishment of lavage tank water with fresh water containing residual free chlorine.
\end{abstract}

Keywords : warm-water lavage toilet seats, toilets, bacterial contamination.

(Received April 8, 2013, accepted May 8, 2014)

\section{Introduction}

Warm-water lavage toilet seats are toilet seats with lavage functions for cleaning the anal and genital regions. According to a consumer trend survey by the Japanese Cabinet Office, the prevalence of warmwater lavage toilet seats reached as high as $70.9 \%$ as of March, 2011[1]. The Japanese are both a highly hygiene-conscious people and a race plagued by conditions such as constipation and hemorrhoids. Upon this background, lavage using electric warm-water toilet seat units has gained wide use as an appliance for maintaining cleanliness of the perianal region after defecation, and for prevention or improvement of constipation and hemorrhoids by stimulating the rectal region with warm water to promote anodermal blood circulation [2]. Furthermore, the potential of warmwater toilet-seat-type lavage units for maintaining hygiene in elderly nursing home residents has been reported in the United States [3]. However, there has yet to be a detailed analysis of bacterial contamination of lavage water, or adherence of fecal bacteria in the gluteal and genital regions due to spattering by lavage water in post-defecation use. we surveyed bacterial contamination of the lavage water and adherence of fecal bacteria in the gluteal and genital regions to examine the problems inherent in the use of toilet-seat warm-water lavage units.

\footnotetext{
*Corresponding Author: Hideki Katano, Matsuki Laboratory Tokai University, School of Health Science, 143 Shimokasuya, Isehara-shi, Kanagawa-ken 259-1193, Japan, Tel: +81-463-90-2058, Fax: +81-463-90-2074, E-mail: katano@tokai-u.jp
} 


\section{Materials and Methods}

Contamination of lavage tank water and chlorine concentrations: 1. Water sampling sites: 1) Bacterial contamination of lavage water; Lavage unit water was collected from tank-type warm-water lavage toilet seats in 85 common households (Company A : rate of Lavage Water $1.3 \mathrm{l} / \mathrm{min}$ ) and 28 public facilities (Company B : rate of Lavage Water $0.90 \mathrm{l} / \mathrm{min}$ ) in Kanagawa Prefecture. 2) Lavage tank-water bacterial contamination in the early morning/afternoon; Lavage unit water was collected in the early morning (6 10 a.m.) and afternoon (2 4 p.m.) from tank-type warm-water lavage toilet seats in 6 common households and 4 public facilities in Kanagawa Prefecture. 3) Free chlorine concentrations in toilet-seat lavage tanks Lavage water were collected as described in 2) above, once a day over 5 days.

Collection of water samples: The lavage nozzle was wiped with ethanol cotton (Orion Yakuhin Kogyo, Co. Ltd.), air-dried, and water was run for 5 seconds to allow for drainage of water within the nozzle itself before collection into $50 \mathrm{~m} l$ sterile centrifuge tubes (Iwaki, Co. Ltd.).

Culture media: Heart infusion (HI) agar was used for estimating total counts of bacteria, P. aeruginosa was isolated in nalidixic acid cetrimide (NAC) agar, and $E$. coli was isolated using deoxycholate-hydrogen sulfide-lactose (DHL) agar (all from Nissui Pharmaceutical, Co. Ltd.).

Enumeration of bacteria and identification: Lavage unit water samples were smeared on agar media (HI, $\mathrm{NAC}, \mathrm{DHL}$ ) and incubated aerobically at $37^{\circ} \mathrm{C}$ for 48 hours, followed by enumeration of colony forming units (CFU).

Evaluation of free chlorine concentration in lavage unit tank water: The collected samples were immediately tested for residual free chlorine by the N,N-diethyl phenylene-diamine (DPD) method.

Bacterial contamination of gluteal and genital regions following defecation and cleansing using toilet-seat lavage units: 1) Sampling areas; Sixty-two samples were collected from the gluteal region and 16 from the genital region of one male subject, in the early morning between July and September, 2008. 2) Culture media; X-Gluc, Magenta-Gal (XM-G) agar food stamp media for $E$. coli and coliform bacteria
(Nissui Pharmaceutical, Co., Ltd.) were used. 3) Sampling areas and methods; Gluteal region samples were collected approximately $5 \mathrm{~cm}$ to the left and right of the anus. Genital samples were collected approximately $10 \mathrm{~cm}$ forward from the anus. Samples of the gluteal and genital region were collected by pressing the food stamps against the sampling area for $5 \mathrm{sec}-$ onds. Control samples were collected by stamping prior to defecation, after wiping the testing area with ethanol cotton (Sanicott, Orion Yakuhin Kogyo, Co. Ltd.), and air drying to remove any direct effects of alcohol. Testing samples were collected after defecation and warm-water lavage. 4) Enumeration of bacteria; Counts of bacteria adherent to the gluteal and genital regions were enumerated (CFU) following aerobic incubation of the food stamps for 24 48 hours.

Statistical analysis: Data were subjected to Welch's $t$ test using SPSS software (Ver. 17).

The study was conducted with approval by the Ethics Committee of Venex Co. Ltd.

\section{Results}

Bacterial contamination of lavage unit water: Figure 1 gives the mean total bacterial counts from lavage tank water samples taken from 85 households and 28 public facilities. The mean total count from the households was $293 \pm 309.1 \mathrm{CFU}$, while that from the public facilities was $109.5 \pm 62.9$, showing significantly high lavage tank water bacterial counts in the common household compared to that in the public facilities ( $P$ $<0.001)$. Moreover, P. aeruginosa and E. coli were isolated from the lavage tank water of a number of households.

Evaluation of free chlorine concentrations of lavage unit tank water: Early morning tank water chlorine concentrations in both the household and public facility samplings were below determinable limits. Afternoon free chlorine concentrations were $>0.1 \mathrm{mg} / \mathrm{l}$ in both household and public facility bidet tank water.

Lavage water bacterial contamination in the early morning and early afternoon: Lavage tank water was collected twice - early morning and early afternoonfrom households $(\mathrm{n}=85)$ and public facilities $(\mathrm{n}=$ 28) and tested for bacterial contamination. The mean bacterial counts from the household samples were sig- 
nificantly different at $798.7 \pm 504.6$ (CFU \pm S.D.) in the early morning, and $30.8 \pm 40.7$ in the afternoon samples $(P<0.001)$. On the other hand, public facility samples yielded mean counts of $57.5 \pm 56.9$ from early morning, and 7.3 \pm 13.2 from afternoon sampleslower again in the afternoon, although the difference was not significant (Fig. 2).

Bacterial contamination of the gluteal and genital regions following lavage unit use: Table 1 shows the E. coli and coliform bacteria counts obtained from the

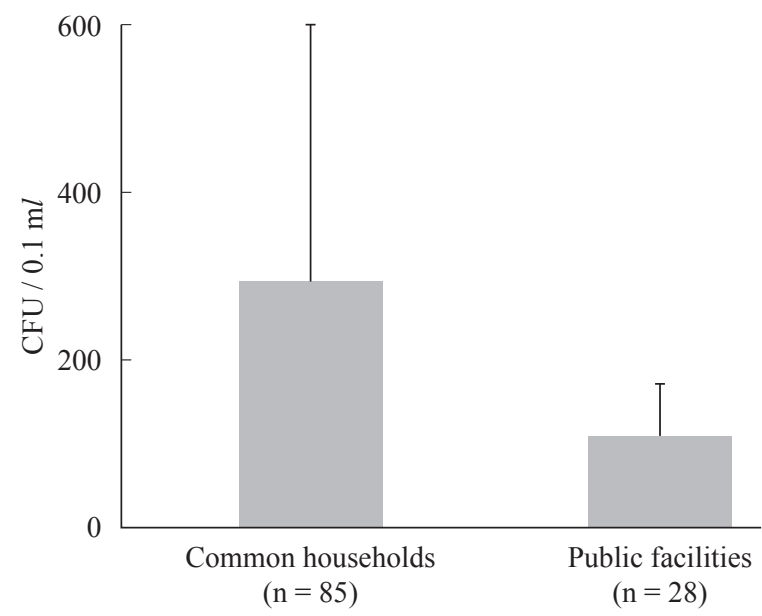

Fig. 1. Number of bacteria in lavage unit tank water.

CFU: colony forming units gluteal and genital regions after defecation and cleansing using the lavage unit.

Free chlorine concentration in lavage tank water: Residual free chlorine regulated by the Waterworks Law to $>0.1 \mathrm{mg} / \mathrm{l}$ upon distribution was not determinable in lavage tank water from both the household and public facility early morning samples. Afternoon samples from the public facility showed $0.3 \mathrm{mg} / l$, and between $0.1 \mathrm{mg} / l \sim \mathrm{N} . \mathrm{D}$. in the household lavage tanks.

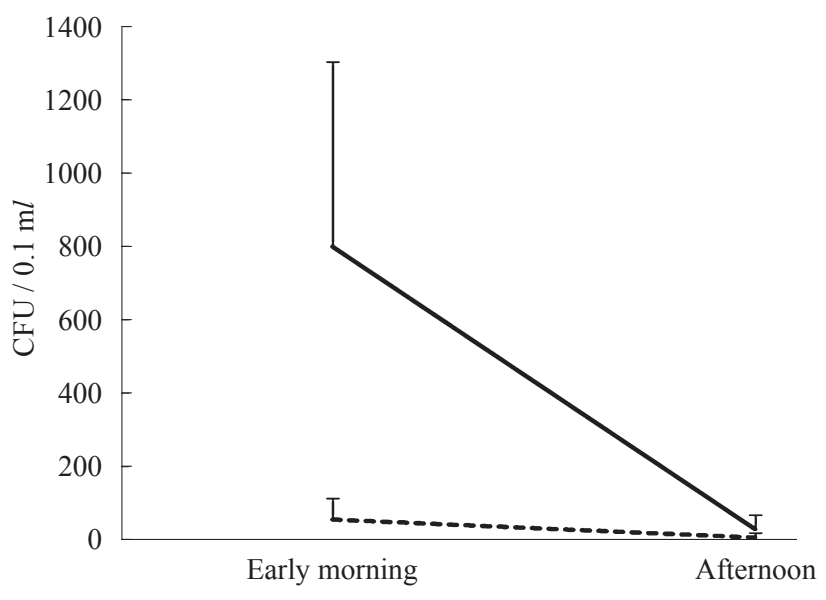

Fig. 2. Number of bacteria in early morning/afternoon samples of lavage unit tank water. - Common households $(n=6),-\ldots-$ : Public facilities $(n=4)$

CFU: colony forming units

Table 1. Adherence of E.coli and coliform bacteria on the gluteal and genital regions

\begin{tabular}{lll}
\hline Before or after lavage & Gluteal region $(\mathrm{n}=62)$ & Genital region $(\mathrm{n}=16)$ \\
\hline Before & ND & ND \\
After & $475.2 \pm 267.5^{*} \mathrm{CFU}$ & $15.8 \pm 9.8^{*} \mathrm{CFU}$ \\
\hline
\end{tabular}

ND: Not detected, *: Mean \pm SD, CFU: colony forming units 


\section{Discussion}

The findings from this survey revealed bacterial contamination of water in the lavage-tank units of warm-water lavage toilet seats. Moreover, the presence of $P$. aeruginosa and E. coli-causative agents of opportunistic infections and cystitis-was confirmed in lavage-tank water in a number of common households. The contaminations were believed to arise from: 1) droplets of loose stools, 2) spattering of contaminated water from the toilet bowl caused by descending feces, and 3) fecal droplets from lavage use after defecation adhering to the nozzle heads, the contaminants then traveling to infiltrate and proliferate within the lavage tank.

The warm-water lavage toilet seats studied in this survey were equipped with lavage unit tanks supplied with tap water. The Waterworks Law in Japan requires a free residual chlorine concentration above $0.1 \mathrm{mg} / \mathrm{l}$ in home tap water at faucet level for purposes of sterilization and disinfection [4]. However, we were unable to detect resideual free chlorine from lavage tank water. This was considered to be the result of evaporation of the chlorine due to heating and long hours of retention within the lavage tank. From this, it was inferred that bacterial proliferation was enabled within the lavage tank devoid of the disinfecting effects of chlorine.

Comparison of bacterial counts of lavage unit water in household and public facility toilet units revealed a 3-fold higher count in household lavage tank water. This was believed to result from higher concentrations of residual chlorine in public facility lavage units due to constant replenishment of fresh water containing residual chlorine from actual lavage unit use and from the automatic nozzle rinse function accompanying each instance of toilet use.

To date, use of the lavage units in warm-water lavage toilet seats has been regarded as an aid in the maintenance of hygiene following excretion, and for alleviating perianal bleeding, swelling, or pain. More- over, there have been reports of lavage unit use being beneficial as improvement of problems with anodermal circulation associated with internal hemorrhoids, anal fissures, and for facilitating recovery from surgical trauma [3].

Our survey demonstrated adherence of fecal E. coli and coliform bacteria on the gluteal and genital surfaces following post-defecation lavage unit use, and spread in the area of contact contamination through toilet-paper use on droplet-infected surfaces.

This survey has demonstrated the danger of bringing about bacterial contamination in the gluteal and genital regions and facilitating the spread of infection following post-defecation use of warm-water lavage toilet seats, which has heretofore been recommended as a sanitary fixture conducive to better hygiene in medical and nursing settings. The findings also indicate the need for prophylactic measures such as glove use against the spread of contact infections from patients using lavage units and from staff caring for such patients.

\section{References}

1. Economic and Social Research Institute, Cabinet office, Government of Japan (2011): Prevalence of principal consumer durables (common household) as of March 2011. http://www.esri.cao.go.jp/jp/stat/shouhi/ shouhi.html.

2. Watanabe K, Watanabe M, Masuda H \& Oono H (1999): Change of anodermal blood flow using warm water irrigation toilet seat device. Jpn. Society of Coloproctology 52: 431-439

3. Cohen-Mansfield J \& Biddison JR (2005): The potential of wash-and-dry toilets to improve the toileting experience for nursing home residents. Gerontologist Oct 45: 694-699

4. Ministry of Health \& Welfare (1957): The water service method enforcement regulations 17. Ministerial Ordinance 45: http://law.e-gov.go.jp/htmldata/S32/S32 F03601000045.html 
温水洗浄便座の局部洗浄水および洗浄後慰部における細菌污染調査

片野 秀樹1, 横山 久美 ${ }^{2}$, 武井 泰 ${ }^{3}$, 田爪 正氣 ${ }^{1}$, 築地 真実 ${ }^{4}$, 松木 秀明 1

${ }^{1}$ 東海大学 健康科学部

2 順天堂大学 医療看護学部

3 順天堂大学 保健看護学部

4 神奈川県立保健福祉大学 保健福祉学部

要旨：温水洗浄便座は, 排便時に拀ける清潔維持, 便秘や瘈の予防·改善に役立つ器具として広く使用されて いる，我々は, 温水洗浄便座局部洗浄水中の細菌, 排便後の局部洗浄水の飛沫によって引き起こされる臂部・股間に 付着する瓷便細菌について調査し, 温水洗浄便座の使用に潜む問題について検討した。本研究結果により, 温水洗浄 便座局部洗浄水中の細菌生息が確認され，さらに一般家庭の局部洗浄水中生菌数は公共施設のものに比して約 3 倍 多いことが明らかとなった。これは, 補水が少頻度の一般家庭においては残留遊離塩素が揮発したためと考元られ

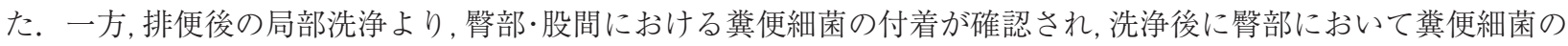
飛沫付着が確認されたことから, 医療従事者は, 局部洗浄水利用者との接触感染に注意が求められる.

キーワード：温水洗浄便座,トイレ, 細菌污染. 